\title{
Screen media exposure in pre-school children in Turkey: the relation with temperament and the role of parental attitudes
}

\author{
Burcu Akın Sar1 ${ }^{1 \oplus}$, Hande Ayraler Taner ${ }^{1 \oplus}$, Zulal Törenli Kaya ${ }^{2 \oplus}$ \\ Departments of ${ }^{1}$ Child and Adolescent Psychiatry and ${ }^{2}$ Psychiatry, Başkent University Faculty of Medicine, Ankara, Turkey.
}

\begin{abstract}
Background. Electronic media have become an important element in the lives of modern children. Devices like televisions, smartphones and tablets are widely used by some parents in order to manage hyperactive, stubborn and impulsive children who need high-intensity stimuli. Consequently, a child's temperament and parental attitudes affect the duration and frequency of 3-7-year-old children's screen (television-smartphone-internet) use. Based on this information, the objective of the present study was to evaluate the relation between screen media exposure, the child's temperament and parental attitudes in 3-7-year-old children.

Methods. The participants of this study were 210 children of 3 to 7 years of age. Rothbart's Child Behavior List was used to assess temperament; the Parenting Attitude Research Instrument was used to determine the parental attitudes. Screen media exposure assessment questionnaire, which included questions about the age the child started using the TV, smartphone and/or internet, and the duration of their daily usage, were filled in with the children's parents.
\end{abstract}

Results. It was found that the increase in activity level, approach and discomfort was negatively correlated to the age the child started watching television, while shyness was positively related to the same phenomenon. The scores of the discomfort temperament subscale had a direct relation to the duration of watching television. Background television is negatively related to attention, inhibitory control, and perceptual sensitivity. Dependency, marital conflict and strictness and authoritarianism parameters were found to be positively related to the duration of playing with a smartphone. Also, in this study we found that negative temperament characteristics adversely affected screen media exposure and poor parenting styles worsen this relationship.

Conclusions. Both temperament and parenting styles affect screen media exposure. In addition, it was understood that parenting styles also affect the relation between temperament and screen exposure. Parental information programs on this subject can eliminate the lack of information related to early screen media exposure in preschool children.

Key words: temperament, parenting, screen, toddler.

Temperament, which represents the child's responses to certain situations, exists from birth and becomes relatively stable over time. Temperament has a biological basis and this can

$凶$ Hande Ayraler Taner

h_ayraler@hotmail.com

Received 13th August 2020, revised 13th February 2021, accepted 26th April 2021.

This study was presented at 9th International Congress on Psychopharmacology \& 5th International Symposium on Child and Adolescent Psychopharmacology, 26-30 April 2017 Antalya and abstract of preliminary reports of this study were published in the journal called "Psychiatry and Clinical Psychopharmacology". provide individual differences about personal reactions to life events. ${ }^{1,2}$ The genetic, biological and environmental factors have an intricate influence on temperament traits. ${ }^{3}$ Genetically based temperament features of the child and the environmental factors like parental attitudes interact with each other, and "goodness of fit" facilitates healthy development. ${ }^{4}$ Parenting is defined as the actions aimed to guarantee the survival and development of the child. ${ }^{5}$

In the literature, it was found that the temperament of the child is associated with parental attitudes, and both temperament and 
parenting have an impact on the characteristics of each other. ${ }^{6}$ As the temperament of the child becomes difficult to manage, so does parenting. Also, incompetent parenting that is demonstrated by means of more authoritarian and insensitive parental attitudes are associated with concomitant stable patterns of difficult temperamental traits and problem behaviors. ${ }^{6}$ It seems that temperament and parental attitudes have a bi-directional relationship.

The American Academy of Pediatrics recommends avoiding digital media use for children younger than 18-24 months old. They also suggested that screen time should be limited to 1 hour or less when the child is 24-month or older; however, screen time should be shared with a parent. ${ }^{7}$ Literature findings emphasize that watching television may impair cognitive development and restrain children from social interaction. Even if the child does not watch television, background television may also be harmful for them. ${ }^{8}$

When studies concerning computer, console, tablet and smartphone games and internet usage are examined, it is apparent that screen media exposure is gradually increasing among children of pre-school age; it is reported for children between the ages of 0 to 8 that, $71 \%$ of them have smart phones while $58 \%$ have tablets. In the literature, studies related to computer and internet usage were mostly conducted with adolescents and in these studies it was determined that problems such as sleeplessness, academic failure, addiction, contact with malicious people, and stealing money from the family in order to spend on online games were highly common for this group. ${ }^{9}$

It was also reported that temperament has a role in the attitude of watching television and children with difficult temperament traits watch more television..$^{10}$ In a study conducted with twoyear-olds, it was found that there was a positive relationship between more authoritarian and permissive parenting styles and the duration of watching television. However, in the same study, it was found that the baby's temperament had no effect on the duration of watching television. ${ }^{11}$ In addition, the content of the program is very important when watching television. The shows that children watch with their parents and informative programs such as "Sesame Street" could be more beneficial for children. However, families with poor parental attitudes do not pay attention to this notion..$^{9,12}$

In light of all this information, the aim of the present study was to investigate the relation between television, tablet/internet and smartphone exposures and temperament, while also investigating the moderator role of parental attitudes of children who are between the ages of 3-7. For this purpose, it was hypothesized that children who have a difficult temperament and are exposed to poor parenting attitudes would have excessive use of media, and the parental attitudes and child's temperament would be effective in their choices of screen media usage (i.e., television, tablet/internet and smartphone usage). As the second theory of the study, it was hypothesized that the child's temperament would directly affect the screen media usage and parenting attitudes would moderate the relation between the child's temperament and choices of screen media usage. As per these hypotheses; the role of parental attitudes in the relationship between the child's temperament traits and screen exposure was investigated in the present study.

\section{Material and Methods}

\section{Sample}

Two hundred and ten children and their families were chosen from day care units and among the healthy children in our hospital. Not being able to read and write to fill in the scales was the exclusion criterion of the study. This study was approved by Başkent University Institutional Review Board and Ethics Committee (Project no: KA15/262). All parents gave written informed consent for themselves and their children. 


\section{Measures}

Sociodemographic information form and screen media assessment questionnaire: It is an information gathering tool prepared by the researchers for collecting sociodemographic and clinical data in accordance with the aim of the study. The form includes questions about the sociodemographic characteristics of the parents and developmental history of the child including birth history, primary caregiver in the first year, diseases, bad memories, sleep, and nutrition routines. In this questionnaire, when the child first used a television, smartphone, and tablet/ internet (as month/old), and the duration of daily television, smartphone and tablet/ internet (as an hour/day) use were also asked. In addition, the parents were asked about watching background television (whether the television is on while the child is playing in the room) and if there was a television in the child's own room. Also, they were asked what the child watches on TV (i.e., cartoons, educational programs, advertisings, all of them), what they did with a smartphone, tablet/internet (i.e., gaming, watching videos, talking on the phone, taking photos, etc.), and for what purpose these devices were given to their children (i.e., for spending time while the mother is doing housework, while feeding, for entertainment, for sleeping, other). Throughout this article, all variables concerning when the child used these digital devices (television, smartphone, tablet/ internet) and the time spent with these devices will be referred to as "screen media exposure".

\section{Children's Behavior Questionnaire-Short Form} $(C B Q)$ : This temperament scale was developed by Putnam and Rothbart. ${ }^{13} \mathrm{CBQ}$ was developed for assessing temperament, which is defined as individual changes in self-regulation and reactivity driven by processes such as genetics, environmental factors, maturation and experiences.

While reactivity is defined as the excitability of sensory, emotional and motor response systems, self-regulation includes systems for regulating them. CBQ was developed on this theoretical basis; it consists of 94 items and measures 15 dimensions of the temperament traits, namely: activity level, anger/frustration, approach, attentional focusing, discomfort, falling reactivity and soothability, fear, high intensity pleasure, impulsivity, inhibitory control, low intensity pleasure, perceptual sensitivity, sadness, shyness, smiling and laughter. On this scale, the parents were asked to rate their children on each item using a 7-point likert scale ranging from "extremely untrue" to "extremely true". There is also a "not applicable" option for situations that may be unrelated to the child. If the average score for a temperament trait is 7 , it is concluded that the temperament trait is very intense for the child. If the average score is 1 , it shows that the temperament trait is very weak. A score of 4 indicates that the temperament is neither intense nor weak. ${ }^{14}$ The Turkish adaptation, validity and reliability study of the scale was conducted by Akın Sarl et al. ${ }^{15}$ and the reliability coefficient was found as .78 .

Parent Attitude Research Instrument (PARI): It is a 4-point Likert-type scale made of 60 items. The scale is used to evaluate the parental attitudes on child rearing. The scale was developed by Schaefer and Bell and Turkish adaptation was conducted by Le Compte et al.in 1978. ${ }^{16,17}$ The internal consistency coefficient of the scale is between .58 and .88 . PARI consists of five dimensions: excessive motherhood, democratic attitude and recognition of equality, hostile and rejective attitude, discord between parents, and an authoritarian attitude. An increase in scores, aside from the "democratic attitude and recognition of equality" dimension, shows negative parental attitudes. ${ }^{17,18}$

\section{Statistical Analyses}

The suitability of the variables to normal distribution was examined using the Kolmogorov - Smirnov and Shapiro Wilk tests. As the variables normally distributed mean value and standard deviation were used for descriptive variables. The relation between sociodemographic characteristics and screen media exposure, and the relation between 
temperament traits and negative parental attitudes for television-computer duration were investigated by Pearson correlation analysis. The Independent sample $t$ test was conducted for group comparison. One-way ANOVA was conducted for investigating group differences and Bonferroni correction was applied.

In this analysis, temperament traits were defined as independent variables because of their genetic origins and the screen media exposure features were defined as dependent variable. While investigating this relation, the parental attitudes were defined as the moderator variables since, as the environmental factors, they can influence present relation positively or negatively. As mentioned before the parental attitudes is an important factor for "goodness of fit". The moderator role of parental attitudes on the relationship between temperament traits and screen media exposure was investigated through regression analysis by using the Process macro of Hayes and Matthes. ${ }^{19}$ Twosided p-values less than .05 were considered statistically significant. All statistical analyses were conducted using SPSS 17.0 for Windows.

\section{Results}

A total of 210 children, 107 girls (51\%) and 103 boys $(49 \%)$, participated in this study. Sociodemographic characteristics, parental attitudes and temperament traits of the sample can be seen in Table I and Table II.

The analyses revealed that there were no differences between girls and boys in terms of the parameters such as age, number of siblings, birth order of children, age of speaking, birth history, illnesses, primary caregiver in the first year, sleeping and feeding problems, type of family, parents' age and occupation, and the parent/caregiver who is currently looking after the child. However, it was observed that the boys had more trauma history $(t=-2.299$, $p=.023)$ and delay in walking $(t=-2.357, p=$ .015) compared to girls. Moreover, considering gender differences, it was found that the boys
Table I. Demographic characteristic of the sample $(N=210)$.

\begin{tabular}{|c|c|c|c|c|}
\hline & Median & $I Q R$ & $N$ & $\%$ \\
\hline \multicolumn{5}{|l|}{ Age } \\
\hline Girls (Total) & & & 107 & 100 \\
\hline Three & & & 27 & 25.2 \\
\hline Four & & & 27 & 25.2 \\
\hline Five & & & 25 & 23.4 \\
\hline Six & & & 28 & 26.2 \\
\hline Boys (Total) & & & 103 & 100 \\
\hline Three & & & 27 & 26.2 \\
\hline Four & & & 25 & 24.3 \\
\hline Five & & & 27 & 26.2 \\
\hline Six & & & 24 & 23.3 \\
\hline \multicolumn{5}{|l|}{ Type of family } \\
\hline Nuclear family & & & 184 & 90.6 \\
\hline Traditional family & & & 18 & 8.9 \\
\hline Divorced family & & & 1 & 0.5 \\
\hline Number of siblings & 2 & 1 & & \\
\hline Birth order & 1 & 1 & & \\
\hline \multicolumn{5}{|l|}{ Parents' education level } \\
\hline \multicolumn{5}{|l|}{ Mother } \\
\hline Primary school & & & 7 & 3.4 \\
\hline Secondary school & & & 10 & 4.8 \\
\hline High school & & & 62 & 29.8 \\
\hline University & & & 110 & 52.9 \\
\hline Master degree & & & 19 & 9.1 \\
\hline \multicolumn{5}{|l|}{ Father } \\
\hline Illiterate & & & 1 & 0.5 \\
\hline Primary school & & & 6 & 2.9 \\
\hline Secondary school & & & 8 & 3.9 \\
\hline High school & & & 47 & 23 \\
\hline University & & & 121 & 59.3 \\
\hline Master degree & & & 21 & 10.3 \\
\hline
\end{tabular}

Parents' employment status

\begin{tabular}{lcc} 
Mother & & \\
Employed & 129 & 62.6 \\
Unemployed & 81 & 37.4 \\
Father & & \\
$\quad$ Employed & 206 & 99.5 \\
$\quad$ Unemployed & 4 & 0.5 \\
Type of birth & & \\
$\quad$ Vaginal birth & 114 & 52.1 \\
Cesarean & 96 & 47.9 \\
\hline
\end{tabular}


Table II. The descriptive characteristics of PARI and the temperament trait.

\begin{tabular}{|c|c|c|c|}
\hline & M & SD & $\mathrm{n}$ \\
\hline \multicolumn{4}{|l|}{ Parental attitudes } \\
\hline Excessive motherhood & 40.95 & 9.46 & 184 \\
\hline Democratic attitude and recognition of equality & 24.05 & 2.96 & 184 \\
\hline Hostile and rejective attitude & 29.54 & 7.14 & 181 \\
\hline Discord between parents & 14.18 & 4.28 & 189 \\
\hline Authoritarian attitude & 35.38 & 8.81 & 177 \\
\hline \multicolumn{4}{|l|}{ Temperament Traits } \\
\hline Activity level & 4.81 & 0.98 & 210 \\
\hline Anger/frustration & 4.36 & 1.09 & 210 \\
\hline Approach & 5.41 & 0.90 & 210 \\
\hline Attentional focusing & 4.56 & 1.18 & 210 \\
\hline Discomfort & 4.24 & 1.28 & 210 \\
\hline Falling reactivity and soothability & 4.44 & 1.02 & 210 \\
\hline Fear & 4.24 & 1.27 & 210 \\
\hline High intensity pleasure & 4.67 & 1.11 & 210 \\
\hline Impulsivity & 4.40 & 1.02 & 210 \\
\hline Inhibitory control & 4.82 & 1.15 & 209 \\
\hline Low intensity pleasure & 5.49 & 0.83 & 210 \\
\hline Perceptual sensitivity & 5.90 & 1.07 & 210 \\
\hline Sadness & 4.63 & 0.83 & 210 \\
\hline Shyness & 3.74 & 1.38 & 210 \\
\hline Smiling and laughter & 5.23 & 1.01 & 210 \\
\hline
\end{tabular}

spend more time on the internet/ with a tablet $(t=-3.663, p=.000)$ and more frequently have a television in their own room $(t=-2.461, p=$ .015) when compared to girls. Considering the relationship between sociodemographic characteristics and screen exposure, the results revealed that the age they started watching television was significantly associated with having a traumatic experience $(t=2.957, p=$ .010), sleep problems $(t=3.199, p=.002)$ and feeding problems $(t=3.149, p=.002)$. Children with delayed speech were introduced to the tablet/internet later $(t=-2.678, p=.011)$. Daily internet/tablet duration was longer in children with delayed walking age $(r=.159, p=$. 025). Apart from this, whether the child has a chronic disease, the type of family, the ages of mother and father, whether the mother and father are employed, the number of siblings, the siblings order and whether there is a delay in walking did not affect screen media exposure $(p>.05)$.
In terms of parent's education level, the results were inconsistent. First of all, as expected, when the mother's education level increased, the children's duration of daily television watching decreased $(r=-.137, p=.005)$. However, the other significant findings revealed that, for the mothers who have a high education level, the children's age of starting watching television $(r=$ $-.143, p=.044)$ and using a smartphone $(r=-.144$, $p=.005)$ decreased. Similarly, as the father's education level increased, the children's age they started using a smartphone decreased $(r=$ $-.167, p=.024)$ and the frequency of background TV increased $(r=.158, p=.029)$. The age they started using a tablet/internet also varied according to the parental education level (for mother $r=-.198, p=.008$; for father $r=-.229, p=$ .002). The higher the education level of fathers, the younger the age of being introduced to a tablet/internet; however, the education level of fathers did not affect the duration of television, smartphone or internet/tablet use. 
Significant differences were also found in terms of the age they started watching television $[F(15,182)=1.69, p=.044$,$] and the time spent$ using a smartphone $[F(2,181)=5.87, p=.003]$. Accordingly, after Bonferroni correction $(p<$ $.05)$, the age they started watching the television was the lowest for those who were raised by a babysitter $(m=15.26$, $s d=9.47)$, whereas their ages were higher when they were raised by mothers $(m=20.59, s d=10.51)$ and grandmothers $(m=23.51, s d=11.52)$. Also, children who were cared for by a babysitter in the first year were introduced to smartphones earlier $(m=26.8$, $s d=14.1)$ (Bonferroni correction $p<.01)$, and children's ages were higher when they were raised by mothers $(m=32.2, s d=15.7)$ and grandmothers $(m=42.0, s d=18.1)$. In addition, for those who were currently caring for the child, there were significant differences in the children's daily time spent on a smartphone $[F(3,192)=3.06, p=.029]$. It is noteworthy that children who were currently cared for by a babysitter had the longest smartphone using time $(m=1.88, s d=1.87)$ and the duration decreased for children who were cared for by grandmothers $(m=1.39, s d=1.87)$, by mothers ( $m$ $=.99, s d=1.31)$, and by daycare center $(m=.75, s d$ $=.87$, non-significant), respectively. The reasons these children used screens and the duration of screen media exposure were also investigated, but there were no statistically significant results. These relationships are shown in Table III.

There were also certain significant correlations between parental attitudes/child's temperament and screen media exposure features, which are shown in Table IV.

In order to test the moderator role of parental attitudes on the relation between children's temperament traits and screen media exposure, a series of moderation analyses were performed. According to the results, 19 of 360 the models were significant and only these findings were reported. The significant results were evaluated based on the critical value obtained via the Johnson and Neyman18 technique, which identifies regions in the range of the moderator variable where the effect of the focal predictor on the outcome is statistically significant and not significant, and pick-a-point approach that involves selecting representative values (e.g., high, moderate, and low) of the moderator variable and then estimating the effect of the focal predictor at those values. ${ }^{19}$ The results were presented according to temperament characteristics:

\section{Anger/Frustration}

When the scores of excessive mothering became lower than the critical value $(\mathrm{CV}=-.9877, B=$ $-2.32, S E=1.18, p=.05,95 \%$ CI $[4.6507,0])$, the negative relation between anger and age of starting to use a smartphone decreased (model: $R^{2}=.05, F(3,161)=3.40, p=.011$, interaction: $B=$ $.28, S E=.11, p=.03$ ). As children's level of anger increase, the duration of using a smartphone tended to increase; if the scores of excessive motherhing became higher than the critical value $(\mathrm{CV}=-3.7115, B=.19, S E=.09, p=.05$, 95\% CI $[-4.8074,0])$, this relation tended to be stronger (model: $R^{2}=.10, F(3,175)=6.78, p=$ .0002 , interaction: $B=.02, S E=.01, p=.01$ ). As children's anger increase, the duration of using a smartphone tended to increase, and when the scores of authoritarian control became higher than the critical value $(C V=-3.4589, B$ $=.19, S E=.10, p=.05,95 \%$ CI $[0, .3856])$, this relation tended to be stronger (model: $R^{2}=.17$, $F(3,171)=11.76, p=.000$, interaction: $B=.03, S E$ $=.00, p=.000$ ). Anger and age of starting using a smartphone had a negative association, and when the scores of authoritarian control became lower than the critical value $(C V=-1.9245, B=$ $-2.40, S E=1.21, p=.05,95 \%$ CI $[0, .3900])$, the strength of this relation became weaker (model: $R^{2}=.04, F(3,156)=2.7, p=.04$, interaction: $B=$ $.29, S E=.13, p=.02)$.

\section{Attentional focusing}

When attentional focusing increased, the duration of internet usage decreased, and when the scores of hostility and rejection became higher than the critical value $(\mathrm{CV}=-2.2857$, $B=-.17, S E=.09, p=.05,95 \%$ CI $[-.3551,0])$, the strength of this relation became weaker 
Table III. The descriptive features of the ways children spend time on screen media and screen media exposure.

\begin{tabular}{|c|c|c|c|c|}
\hline & \multicolumn{4}{|c|}{ What they watching on TV. } \\
\hline & $\begin{array}{l}\text { Cartoons } \\
(\mathrm{n}=192)\end{array}$ & $\begin{array}{l}\text { Educational } \\
\text { programs } \\
(\mathrm{n}=6)\end{array}$ & $\begin{array}{l}\text { Advertisements } \\
\qquad(\mathrm{n}=3)\end{array}$ & $\begin{array}{l}\text { All of them } \\
\qquad(\mathrm{n}=1)\end{array}$ \\
\hline & $M \pm S D$ & $M \pm S D$ & $M \pm S D$ & $M \pm S D$ \\
\hline Age they started watching TV & $20.6 \mathrm{~m} \pm 10.8$ & $23 \mathrm{~m} \pm 7.9$ & $9 \mathrm{~m} \pm 4.2$ & $24 \mathrm{~m} \pm 0$ \\
\hline $\begin{array}{l}\text { Age they started using } \\
\text { smartphones }\end{array}$ & $33.4 \mathrm{~m} \pm 16$ & $50 \mathrm{~m} \pm 24.4$ & $21.33 \mathrm{~m} \pm 17.24$ & $24 \mathrm{~m} \pm 0$ \\
\hline $\begin{array}{l}\text { Age they started using a } \\
\text { tablet/internet }\end{array}$ & $36.9 \mathrm{~m} \pm 16.9$ & $56 \mathrm{~m} \pm 19.5$ & $39 \mathrm{~m} \pm 12.7$ & $12 \mathrm{~m} \pm 0$ \\
\hline Daily hours of watching TV & $2.35 \mathrm{~h} \pm 2.86$ & $1.3 \mathrm{~h} \pm 0.5$ & $0.5 h \pm 0.5$ & $5 \mathrm{~h} \pm 0$ \\
\hline $\begin{array}{l}\text { Daily hours of using a } \\
\text { smartphone }\end{array}$ & $0.9 h \pm 1.3$ & $0.2 \mathrm{~h} \pm 0.4$ & $0.6 \mathrm{~h} \pm 0.5$ & $5 h \pm 0$ \\
\hline $\begin{array}{l}\text { Daily hours of using the } \\
\text { internet }\end{array}$ & $1 \mathrm{~h} \pm 1.24$ & $0.4 \mathrm{~h} \pm 0.5$ & $0.6 \mathrm{~h} \pm 0.54$ & $5 \mathrm{~h} \pm 0$ \\
\hline
\end{tabular}

\begin{tabular}{|c|c|c|c|c|c|}
\hline & \multicolumn{5}{|c|}{ What are they doing with the smartphones? } \\
\hline & $\begin{array}{l}\text { Playing games } \\
\qquad(\mathrm{n}=130)\end{array}$ & $\begin{array}{l}\text { Watching } \\
\text { videos } \\
(\mathrm{n}=24)\end{array}$ & $\begin{array}{l}\text { Taking photos } \\
\quad(\mathrm{n}=10)\end{array}$ & $\begin{array}{l}\text { Talking on the } \\
\text { phone } \\
(\mathrm{n}=2)\end{array}$ & $\begin{array}{l}\text { All of them } \\
\quad(\mathrm{n}=1)\end{array}$ \\
\hline & $M \pm S D$ & $M \pm S D$ & $M \pm S D$ & $M \pm S D$ & $M \pm S D$ \\
\hline Age they started watching TV & $20.03 \mathrm{~m} \pm 10.71$ & $18.47 \mathrm{~m} \pm 9.39$ & $23.4 \mathrm{~m} \pm 12.4$ & $12 \mathrm{~m} \pm 4.9$ & $24 \mathrm{~m} \pm 0$ \\
\hline $\begin{array}{l}\text { Age they started using } \\
\text { smartphones }\end{array}$ & $33.79 \mathrm{~m} \pm 15.70$ & $32.16 \mathrm{~m} \pm 16.53$ & $25.11 \mathrm{~m} \pm 12.57$ & $19.2 \mathrm{~m} \pm 11.54$ & $24 \mathrm{~m} \pm 0$ \\
\hline $\begin{array}{l}\text { Age they start using a tablet/ } \\
\text { internet }\end{array}$ & $35.85 \mathrm{~m} \pm 16.65$ & $33.91 \mathrm{~m} \pm 18.88$ & $33.66 \mathrm{~m} \pm 17.60$ & $40.5 \mathrm{~m} \pm 16.52$ & $12 \mathrm{~m} \pm 0$ \\
\hline Daily hours of watching TV & $2.21 \mathrm{~h} \pm 1.53$ & $1.79 \mathrm{~h} \pm 1.22$ & $1.9 \mathrm{~h} \pm 1.3$ & $1.3 \mathrm{~h} \pm 1.1$ & $5 \mathrm{~h} \pm 0$ \\
\hline $\begin{array}{l}\text { Daily hours of using a } \\
\text { smartphone }\end{array}$ & $1.26 \mathrm{~h} \pm 1.51$ & $0.6 \pm 0.6$ & $0.25 \mathrm{~h} \pm 35$ & $0.62 \mathrm{~h} \pm 0.94$ & $5 \mathrm{~h} \pm 0$ \\
\hline \multirow{4}{*}{$\begin{array}{l}\text { Daily hours of using the } \\
\text { internet }\end{array}$} & $1.1 \mathrm{~h} \pm 1.3$ & $1 \mathrm{~h} \pm 0.8$ & $0.3 \mathrm{~h} \pm 0.53$ & $1.7 \mathrm{~h} \pm 1.4$ & $5 \mathrm{~h} \pm 0$ \\
\hline & \multicolumn{5}{|c|}{ What are they doing on the internet? } \\
\hline & $\begin{array}{l}\text { Playing games } \\
\qquad(\mathrm{n}=123)\end{array}$ & $\begin{array}{l}\text { Watching } \\
\text { videos } \\
(\mathrm{n}=21)\end{array}$ & $\begin{array}{l}\text { No internet } \\
\quad(\mathrm{n}=21)\end{array}$ & $\begin{array}{l}\text { Social media } \\
\qquad(\mathrm{n}=1)\end{array}$ & $\begin{array}{l}\text { All of them } \\
\quad(\mathrm{n}=1)\end{array}$ \\
\hline & $M \pm S D$ & $M \pm S D$ & $M \pm S D$ & $M \pm S D$ & $M \pm S D$ \\
\hline Age they started watching TV & $21.04 \mathrm{~m} \pm 10.76$ & $19.73 m \pm 11.57$ & $24.10 \mathrm{~m} \pm 12$ & $10 \mathrm{~m} \pm 0$ & $24 \mathrm{~m} \pm 0$ \\
\hline $\begin{array}{l}\text { Age they started using } \\
\text { smartphones }\end{array}$ & $33.08 \mathrm{~m} \pm 16.35$ & $32.24 \mathrm{~m} \pm 15.75$ & $39.66 \mathrm{~m} \pm 19.1$ & $42 \mathrm{~m} \pm 0$ & $12 \mathrm{~m} \pm 0$ \\
\hline $\begin{array}{l}\text { Age they started using a } \\
\text { tablet/internet }\end{array}$ & $38.26 \mathrm{~m} \pm 17.48$ & $34.15 \mathrm{~m} \pm 16.52$ & $49.5 \mathrm{~m} \pm 17.18$ & $42 \mathrm{~m} \pm 0$ & $12 \mathrm{~m} \pm 0$ \\
\hline Daily hours of watching TV & $2.57 \mathrm{~h} \pm 3.42$ & $1.78 \mathrm{~h} \pm 1.58$ & $1.59 \mathrm{~h} \pm 1.04$ & $1 \mathrm{~h} \pm 0$ & $5 \mathrm{~h} \pm 0$ \\
\hline $\begin{array}{l}\text { Daily hours of using a } \\
\text { smartphone }\end{array}$ & $0.95 \mathrm{~h} \pm 1.2$ & $0.9 \mathrm{~h} \pm 1.2$ & $0.88 \mathrm{~h} \pm 1.73$ & $2 \mathrm{~h} \pm 0$ & $5 \mathrm{~h} \pm 0$ \\
\hline $\begin{array}{l}\text { Daily hours of using the } \\
\text { internet }\end{array}$ & $1.35 \mathrm{~h} \pm 1.2$ & $1.1 \mathrm{~h} \pm 1.2$ & - & - & $5 \mathrm{~h} \pm 0$ \\
\hline
\end{tabular}

$\mathrm{m}$ : months of age, h: hours of day 
Table IV. The correlations between screen media exposure features and parental attitudes/temperament traits.

\begin{tabular}{|c|c|c|c|c|c|c|}
\hline & $\begin{array}{c}\text { Age they } \\
\text { started } \\
\text { watching } \\
\text { TV }\end{array}$ & $\begin{array}{c}\text { Age they } \\
\text { started } \\
\text { using a } \\
\text { smartphone }\end{array}$ & $\begin{array}{l}\text { Age they } \\
\text { started } \\
\text { using a } \\
\text { tablet/ } \\
\text { internet }\end{array}$ & $\begin{array}{c}\text { Daily } \\
\text { hours of } \\
\text { watching } \\
\text { TV }\end{array}$ & $\begin{array}{l}\text { Daily hours } \\
\text { of using a } \\
\text { smartphone }\end{array}$ & $\begin{array}{c}\text { Daily hours } \\
\text { of using } \\
\text { a tablet/ } \\
\text { internet }\end{array}$ \\
\hline & $r$ & $r$ & $r$ & $r$ & $r$ & $r$ \\
\hline \multicolumn{7}{|l|}{ Parental attitudes } \\
\hline Excessive motherhood & 0.002 & 0.068 & 0.019 & 0.076 & $0.176^{*}$ & 0.130 \\
\hline $\begin{array}{l}\text { Democratic attitude and } \\
\text { recognition of equality }\end{array}$ & 0.133 & 0.150 & 0.071 & 0.032 & 0.021 & 0.010 \\
\hline Hostile and rejective attitude & 0.059 & -0.067 & -0.094 & 0.020 & 0.094 & 0.144 \\
\hline Discord between parents & -0.039 & 0.012 & -0.124 & 0.017 & $0.172^{*}$ & 0.091 \\
\hline Authoritarian attitude & 0.76 & 0.067 & -0.048 & 0.127 & $0.253^{* *}$ & $0.178^{*}$ \\
\hline \multicolumn{7}{|l|}{ Temperamental traits } \\
\hline Activity level & $-0.166^{*}$ & -0.089 & -0.125 & 0.028 & 0.016 & 0.095 \\
\hline Anger/frustration & -0.091 & -0.123 & -0.144 & 0.007 & $0.223^{* *}$ & 0.106 \\
\hline Approach & $-0.167^{*}$ & $-0.150^{*}$ & -0.076 & 0.019 & -0.072 & -0.054 \\
\hline Attentional focusing & 0.066 & 0.149 & $0.172^{*}$ & 0.009 & $-0.236^{* *}$ & $-0.271^{* *}$ \\
\hline Discomfort & $-0.153^{*}$ & -0.017 & 0.056 & $0.156^{*}$ & -0.015 & -0.029 \\
\hline Falling reactivity and soothability & 0.008 & -0.013 & 0.038 & -0.024 & $-0.161^{*}$ & -0.106 \\
\hline Fear & -0.025 & 0.118 & 0.114 & -0.002 & -0.021 & $-0.151^{*}$ \\
\hline High intensity pleasure & -0.094 & -0.047 & -0.102 & 0.000 & $0.204^{* *}$ & $0.226^{* *}$ \\
\hline Impulsivity & $-0.157^{*}$ & -0.71 & -0.067 & -0.032 & 0.043 & 0.092 \\
\hline Inhibitory control & 0.000 & 0.131 & $0.214^{* *}$ & -0.103 & $-0.343^{* *}$ & $-0.368^{* *}$ \\
\hline Low intensity pleasure & -0.057 & 0.027 & 0.050 & 0.028 & $-0.146^{*}$ & $-0.174^{*}$ \\
\hline Perceptual sensitivity & -0.072 & 0.068 & 0.122 & -0.026 & $-0.252^{* *}$ & $-0.264^{* *}$ \\
\hline Sadness & -0.013 & 0.082 & $0.171^{*}$ & -0.121 & $-0.142^{*}$ & $-0.165^{*}$ \\
\hline Shyness & $0.155^{*}$ & $0.187^{*}$ & 0.125 & -0.085 & -0.006 & $-0.154^{*}$ \\
\hline Smiling and laughter & -0.038 & -0.055 & -0.008 & 0.060 & -0.081 & -0.086 \\
\hline
\end{tabular}

Note. ${ }^{*} p<.05,{ }^{* *} p<.01$

(model: $R^{2}=.14, F(3,173)=9.47, p=.0000$, interaction: $B=-.04, S E=.01, p=.001)$. When attentional focusing increased, the duration of internet usage decreased, and if the scores of authoritarian control became higher than the critical value $(\mathrm{CV}=-6.3532, B=-.18, S E=.09$, $p=.05,95 \%$ CI $[-.3720,0])$, the strength of this relation became weaker (model: $R^{2}=.13, F(3$, $171)=9.06, p=.0000$, interaction: $B=-.02, S E=$ $.00, p=.015)$.

\section{Discomfort}

Discomfort and duration of watching TV had a positive association, and if the scores of authoritarian control became higher than the critical value $(\mathrm{CV}=-2.5923, B=.34, S E=.17$, $p=.05,95 \%$ CI $[0, .6912])$, the strength of this relation tended to be stronger (model: $R^{2}=.07$, $F(3,173)=4.78, p=.0031$, interaction: $B=.05, S E$ $=.02, p=.02)$.

\section{Falling reactivity/soothability}

As children's level of falling reactivity/ soothability increased, the age of starting to watch TV tended to decrase. If the scores of excessive mothering became lower than the critical value $(C V=-4.5660, B=-1.84, S E=.93, p$ $=.05,95 \% \mathrm{CI}[-3.6862,0])$, this relation tended to 
become weaker; but if the scores became higher than the critical value $(C V=9.9264, B=2.15, S E$ $=1.09, p=.05,95 \%$ CI $[0,4.3028])$, this relation tended to be stronger (model: $R^{2}=.05, F(3,173)=$ $3.35, p=0.02$, interaction: $B=.27, S E=.08, p=.001$ ). Children's level of falling reactivity/soothability and the duration of using a smartphone had a positive but non-significant association $(p=$ .059). When the scores of excessive mothering became higher than the critical value $(\mathrm{CV}=$ $.2546, B=-.19, S E=.10, p=.05,95 \%$ CI [-.3991, $0])$, the strength of this relation became weaker and significant (model: $R^{2}=.09, F(3,175)=$ 5.93, $p=.0007$, interaction: $B=-.02, S E=.01, p$ $=.011$ ). As children's level of falling reactivity/ soothability increased, the duration of using a smartphone tended to decrease. If the scores of authoritarian control became higher than the critical value $(\mathrm{CV}=-1.2450, B=-.20, \mathrm{SE}=.10$, $p=.05,95 \%$ CI $[-.4193,0])$ the strength of this relation became weaker (model: $R^{2}=.12, F(3$, $171)=8.03, p=.0000$, interaction: $B=-.03, S E=$ $.01, p=.015)$.

\section{Inhibitory control}

Although the negative relationship between the children's level of inhibitory control and age they started watching TV was non-significant $(p=.69)$, if the scores of democratic attitudes became lower than the critical value $(\mathrm{CV}=$ $-2.3883, B=-1.85, S E=.93, p=.05,95 \%$ CI [-3.7034, $0])$, this relationship tended to become weaker and significant (model: $R^{2}=.04, F(3,173)=2.93$, $p=.034$, interaction: $B=.56, S E=.24, p=.022$ ). As children's level of inhibitory control increased, the duration of using internet tended to decrease. If the scores of hostility and rejection became higher than the critical value $(\mathrm{CV}=-8.0781, B$ $=-.26, S E=.13, p=.05,95 \%$ CI $[-.5200,0])$, this relation tended to become weaker (model: $R^{2}$ $=.18, F(3,173)=13.5, p=.0000$, interaction: $B$ $=-.02, S E=.01, p=.049)$. As children's level of inhibitory control increased, the duration of internet usage tended to decrease. If the scores of authoritarian control became higher than the critical value $(\mathrm{CV}=-7.6616, B=-.22, S E=.11, p$ $=.05,95 \%$ CI $[-.4547,0])$, this relation tended to become weaker (model: $R^{2}=.18, F(3,171)=$ $12.90, p=.0000$, interaction: $B=-.02, S E=.01, p$ $=.027$ ).

\section{Low intensity pleasure}

When children's low intensity pleasure increased, the age they started watching TV decreased, but this relation was non-significant $(p=.12)$. However, when the scores of democratic attitudes became lower than the critical value $(\mathrm{CV}=-.6130, B=-1.98, \mathrm{SE}=1.00, p=.05,95 \% \mathrm{CI}$ $[-3.9797,0])$, the relationship became significant and the strength of this relation become weaker (model: $R^{2}=.05, F(3,173)=3.31, p=.021$, interaction: $B=.72, S E=.35, p=.044)$. When children's low intensity pleasure increased, the duration of tablet usage decreased, but this relation was non-significant $(p=.10)$. However, if the scores of hostility and rejection became higher than the critical value $(\mathrm{CV}=.7861, B=$ $-.22, S E=.11, p=.05,95 \%$ CI [-.4462, 0]), their interaction became significant and the strength of this relation become weaker (model: $R^{2}=.08$, $F(3,173)=5.46, p=.0013$, interaction: $B=-.04, S E$ $=.01, p=.005)$.

\section{Sadness}

As children's level of sadness increased, the age they started using a tablet tended to increase. If the scores of excessive mothering become higher than the critical value $(C V=-.4271, B=3.08, S E$ $=1.56, p=.05,95 \% \mathrm{CI}[0,6.1644])$ the strength of this relation tended to be stronger (model: $R^{2}=$ $.06, F(3,156)=3.37, p=.019$, interaction: $B=.46$, $S E=.18, p=.014)$. As children's level of sadness increased, the duration of watching TV tended to decrease, but this association was nonsignificant $(p=.061)$. However, when the scores of excessive mothering become higher than the critical value $(\mathrm{CV}=.3535, B=-.50, S E=.25, p=$ $.05,95 \%$ CI $[-1.0096,0]$, the interaction became significant and the strength of relationship between sadness and duration of watching TV tended to become weaker (model: $R^{2}=.05, F(3$, $178)=3.19, p=.024$, interaction: $B=-.07, S E=.03$, $p=.016)$. As children's level of sadness increased, the duration of watching TV tended to decrease, 
but this relation was non-significant $(p=.63)$. If the scores of authoritarian control became lower than the critical value $(\mathrm{CV}=-12.6720, B=.89$, $S E=.45, p=.05,95 \% \mathrm{CI}[0,1.7881])$ this relation tended to become stronger; if the scores became higher than the critical value $(\mathrm{CV}=.2827, B=$ $-.50, S E=.25, p=.05,95 \%$ CI $[-1.0189,0])$ this relationship tended to become weaker. In both cases, the interactions were significant (model: $R^{2}=.08, F(3,173)=5.43, p=.001$, interaction: $B=$ $-.10, S E=.03, p=.0010)$.

\section{Shyness}

As children's level of shyness increased, the duration of watching TV tended to decrease. If the scores of authoritarian control become lower than the critical value $(C V=-9.0304, B$ $=.41, S E=.21, p=.05,95 \% \mathrm{CI}[0, .8319])$, this relationship tended to become stronger; but if the scores became higher than the critical value $(\mathrm{CV}=-.4326, B=-.30, \mathrm{SE}=.15, p=.05,95 \% \mathrm{CI}$ $[-.6057,0])$ this relationship tended to become weaker (model: $R^{2}=.12, F(3,173)=8.23, p=$ .0000 , interaction: $B=-.08, S E=.01, p=.0000$ ).

\section{Discussion}

This study investigated the relationship between screen media exposure and child's temperament, and the effects of parental attitudes on this relationship. The sample of the present study started watching television at about 20 months old; the average duration and the age of beginning to watching television were compatible with previous studies. ${ }^{20-24}$ However, it was remarkable that the duration of smartphone usage was longer than in previous studies. ${ }^{25}$ Studies conducted in the USA have shown that watching videos are the most commonly purpose of screen media usage. ${ }^{25} \mathrm{In}$ a recent study that investigated 3-5 year old's smartphone and tablet use in the USA revealed that the most common used applications are YouTube and YouTubeKids. ${ }^{26}$ In the present study which was conducted in Turkey, it was found that playing video games are the most common purpose of screen media usage.
These differences are thought to be associated with cultural differences and Turkey's being a developing country. Moreover, as in other developing countries, boys are perceived as more valuable than girls in the Turkish society. ${ }^{27}$ The fact that there are more TVs in boys' rooms may be related to this situation. Similar to the present study, in a study conducted in the USA, it was found that male adolescents have more video game systems than girls and these systems are found to be more common in boys' rooms than girls. ${ }^{28}$ In this study, contrary to Western studies, the higher the level of educationof the parents, the more media devices seem to exist in their houses. ${ }^{25}$ In addition, the rate of working with care-givers was also higher for this group. This can be explained by the fact that families with higher education levels are likely to have a higher income and therefore purchasing power, making it easier for them to access screen media tools and private care services.

Children with a difficult temperament (i.e., activity level, discomfort, impulsivity) were permitted to watch television at earlier ages by their parents in this study. It was observed as a difficult temperament trait that, when the discomfort increased, the duration of watching television also increased. Studies showed that children with difficult temperament traits watch more television and this could be regarded as a coping mechanism..$^{10,29}$ Similarly, mothers of children who had difficulty in self-regulation at the age of 2 were also allowed more television time. ${ }^{30}$ When these studies were evaluated together, the temperament trait seems to affect the screen exposure in early infancy as well as in the pre-school period. In a study conducted by Munzer et al. ${ }^{8}$, it was found that children who had difficulty in self-regulation in the pre-school period were exposed to increased durations of screen and background TV. Similarly, in this study, self-regulation parameters such as attentional focusing and inhibitory control were observed to be lower for children having background television. The poor perceptual sensitivity in this study is related to background TV exposure. In other 
words, temperament traits affect the preference of screen usage in positive and negative ways.

For the participants of this study, it is noteworthy that children with easy temperament traits did not have the internet at their homes. Parents of children with an easy temperament do not use the internet. Parent's relationship with electronic media devices is known to affect the use of these devices by children. ${ }^{31}$ In studies, it was found that difficult temperament traits were related to internet addiction. ${ }^{32,33}$ It is also known from previous studies that temperament traits are inherited. ${ }^{34,35}$ Therefore, it seems that the easy temperament traits of the parents can limit their internet usage and in this way, their children can also be protected both environmentally and genetically.

No relationship was found between parental attitudes and television usage in this study. However, such a relationship was found between poor parenting attitudes and smartphone and tablet/internet usage durations. This shows us that media devices other than television are becoming more prominent for young children. As recognized from the literature, the smartphone is a device that creates an important screen exposure that is increasingly used in children between the ages of $0-8 .{ }^{25}$ It was suggested that the parents of children between ages of 3 to 6 did not want their children to watch television, but they did not think the same way for smartphone usage. Studies revealed that the duration of television watching increases with a permissive parenting attitude. ${ }^{36}$ Howe et al. ${ }^{11}$ found that both permissive and authoritarian mothers allowed more television time. In a study conducted with 5-year-old children, it was found that authoritarian parents allowed less use of smartphone and game consoles for their children, but the duration of the television was not related to any parenting attitude. ${ }^{37}$ It has also been shown that good parenting attitudes in mothers of elementary school children also decreased smartphone usage. ${ }^{38}$ However, as revealed in the present study, authoritarian parents let their children use the internet/tablet and smartphone for more hours and used this screen exposure to get their own work done or to feed them. In other words, mothers use the screen as a "digital parent" and self-substitute. Cultural differences within the family can also explain the differences in screen media usage of these parenting attitudes. Therefore, it can be considered that the reasons for these differences should be determined by longitudinal studies.

In the literature, there are conflicting results regarding the relationship between parenting attitudes, temperament traits and screen media exposure. Some of them have found that parenting attitudes have an effect on screen media usage, while in some others, the temperament traits were found to be effective. ${ }^{30,36,37,39}$ In a study conducted with adolescents, it was found that parenting attitudes affected temperament traits and made internet use problematic. ${ }^{40}$

In this study, it was seen that, when difficult temperament traits and bad parental attitudes were combined, screen media exposure increased. While smartphone exposure increased with the anger temperament trait, excessive mothering and authoritarian control parental attitudes could reinforce this relationship. While discomfort temperament traits prolonged television duration, authoritarian control parental attitudes increased this relationship. It was noted that the daily smartphone usage shortened as soothability increased and this relationship was affected by authoritarian control. Easy temperament traits such as attentional focusing and inhibitory control reduced the duration of internet usage, and poor parenting features such as hostility/rejection and authoritarian control weakened this relation. Additionally, for children with easy temperament traits, screen exposure was low, and as a moderator, bad parenting attitudes seem to reduce this relationship. In other words, when difficult temperament and bad parenting come together, negative results were observed; even if they have an easy temperament, children with bad parenting may be more exposed to screen media. It is stated in a study by Rubinet al. ${ }^{41}$ 
that even worse results could be observed when inhibited temperament traits and excessive mothering were combined. In this study, the reason for sad children to start using tablets/ internet earlier may be due to the overprotection of mothers. Mothers endeavor to reduce the sadness of their children. Similarly, in the present study, it was found that the duration of daily television watching decreased as sadness increased and excessive mothering parental attitudes negatively affected this relationship. In other words, this parental attitude increased the duration of daily television watching. Apart from this, it was observed that parental attitude of authoritarian control had a binary effect on the relationship between unhappiness and shyness, and the duration of watching television. It was observed that daily television watching duration decreased as sadness and shyness increased, and these relations strengthened when the parental attitude of authoritarian control was low. However, it is noteworthy that when the authoritarian control increased, these relations were also negatively affected, namely the duration of watching television increased. As a result, the models of the present study showed that bad parenting attitudes increased screen media exposure while good parenting reduced it. In order to understand the effects of parental attitudes on the relationship between other temperament traits and screen media exposure, further studies should be conducted.

This is a comprehensive study that aimed to examine the association between temperament traits and screen media exposure, and the moderator role of parental attitudes on this relationship. In this study, the role of parental attitudes on the link between temperament traits and screen media exposure was investigated for the first time. These results can be a guide for future studies. In addition, the duration of television, smartphone and tablet/internet usages were examined separately and the differences between the usage purposes were also analysed. The study has some limitations, the first of which is the limited number of participants who contributed to the study. The second limitation is the fact that previous experiences were questioned while collecting data, which can be regarded as a cause for recall bias. In order to solve this problem, developing applications which monitor the use of screen media was suggested by Barr et al. ${ }^{42}$

In the light of the results of the present study, it was determined that the main reason for parents to expose their children to the screen at an early age may be due to their lack of information about the importance of the subject. Therefore, information programs about parenting, temperament management and the negative consequences of screen exposure may decrease the screen exposure time of pre-school children.

\section{Acknowledgements}

The authors would like to acknowledge Selvi Kayıpmaz for her statistical assistance, Artun Törenli for his valuable feedback while proof reading the article and all the participants who were involved in the study.

\section{Author contribution}

The authors confirm contribution to the paper as follows: study conception and design: BAS, HAT, ZTK; data collection: BAS, HAT, ZTK; analysis and interpretation of results: BAS, HAT, ZTK; draft manuscript preparation: BAS, HAT, ZTK. All authors reviewed the results and approved the final version of the manuscript.

\section{Ethical approval}

This study was approved by Instituonal Review Board and Ethics Commitee (Project no: KA15/262) on 12.08.2015 and supported by Baskent University Research Fund.

\section{Conflict of interest}

The author has no conflict of interest to declare. 


\section{REFERENCES}

1. Goldsmith HH, Buss AH, Plomin R, et al. Roundtable: what is temperament? Four approaches. Child Dev 1987; 58: 505-529.

2. Kristal J. The Temperament Perspective: Working with Children's Behavioral Styles. (1st ed) Baltimore: Paul H Brookes Publishing, 2005.

3. Shiner RL, Buss KA, McClowry SG, et al. What is temperament now? Assessing progress in temperament research on the Twenty-Fifth Anniversary of Goldsmith et al. Child Dev Perspect 2012; 6: 436-444.

4. Thomas A, Chess S. Temperament and Development. New York: Brunner/Mazel, 1977.

5. Hoghughi M. Parenting - An Introduction. In: MS, Long N (eds). Handbook of Parenting: Theory and Research for Practice. (1st ed) London: SAGE Publication, 2004: 1-17.

6. Akın Sarı B. Çocuk davranış listesi kısa formunun Türkçe geçerlilik-güvenilirlik çalışması ve 3-6 yaş çocuklarında mizacın etyolojisinin araştırılması. Yayınlanmamış Doktora Tezi, Gazi Üniversitesi Tıp Fakültesi, Ankara, 2009.

7. American Academy of Pediatrics. Council on Communications and Media. Media and Young Minds. Pediatrics 2016; 138: e20162591.

8. Munzer TG, Miller AL, Peterson KE, et al. Media exposure in low-income preschool-aged children is associated with multiple measures of self-regulatory behavior. J Dev Behav Pediatr 2018; 39: 303-309.

9. Yavuzer H, Şirin MR. 1. Türkiye Çocuk ve Medya Kongresi. Bildiriler Kitabı. Cilt 2, İstanbul: Çocuk Vakfı Yayınları, 2013.

10. Sherry JL. Toward an etiology of media use motivations: the role of temperament in media use. Commun Monogr 2001; 68: 274-288.

11. Howe AS, Heath AM, Lawrence J, et al. Parenting style and family type, but not child temperament, are associated with television viewing time in children at two years of age. PLoS One 2017; 12: e0188558.

12. Cole CF, Lee JH, Bucuvalas A, Sirali Y. Seven essential elements for creating effective children's media to promote peace building: lessons from International Coproductions of Sesame Street and Other Children's Media Programs. New Dir Child Adolesc Dev 2018; 2018: 55-69.

13. Putnam SP, Rothbart MK. Development of short and very short forms of the Children's Behavior Questionnaire. J Pers Assess 2006; 87: 102-112.
14. Rothbart MK, Ahadi SA, Hershey KL, Fisher P. Investigations of temperament at three to seven years: the Children's Behavior Questionnaire. Child Dev 2001; 72: 1394-1408.

15. Sarı BA, İşeri E, Yalçın Ö, Aslan AA, Şener Ş. Çocuk davranış listesi kısa formunun Türkçe güvenilirlik çalışması ve geçerliliğine ilişkin ön çalışma. Klinik Psikiyatri Dergisi 2012; 15: 135-143.

16. Schaefer ES, Bell RQ. Development of a parental attitude research instrument. Child Dev 1958; 29: 339-361.

17. LeCompte G, LeCompte A, Özer S. Üç sosyoekonomik düzeyde Ankaralı annelerin çocuk yetiştirme tutumları: bir ölçek uyarlaması. Türk Psikoloji Dergisi 1978; 1: 5-8.

18. Küçük AŞ. The validity of the Turkish form of the PARI subscales II, III, IV. Yayınlanmamış Yüksek Lisans Tezi, İstanbul: Boğaziçi Üniversitesi Sosyal Bilimler Enstitüsü, Eğitim Bilimleri Bölümü, 1987.

19. Hayes AF, Matthes J. Computational procedures for probing interactions in OLS and logistic regression: SPSS and SAS implementations. Behav Res Methods 2009; 41: 924-936.

20. Conners NA, Tripathi SP, Clubb R, Bradley RH. Maternal characteristics associated with television viewing habits of low-income preschool children. J Child Fam Stud 2007; 16: 415-425.

21. Zimmerman FJ, Christakis DA, Meltzoff AN. Television and DVD/video viewing in children younger than 2 years. Arch Pediatr Adolesc Med 2007; 161: 473-479.

22. Vandewater EA, Rideout VJ, Wartella EA, Huang X, Lee JH, Shim M. Digital childhood: electronic media and technology use among infants, toddlers, and preschoolers. Pediatrics 2007; 119: e1006-e1015.

23. Dennison BA, Erb TA, Jenkins PL. Television viewing and television in bedroom associated with overweight risk among low-income preschool children. Pediatrics 2002; 109: 1028-1035.

24. Jordan AB, Hersey JC, McDivitt JA, Heitzler CD. Reducing children's television-viewing time: a qualitative study of parents and their children. Pediatrics 2006; 118: e1303-e1310.

25. Commonsense Media. The Common Sense Census: Media Use by Kids Age Zero to Eight. Available at: https://www.commonsensemedia.org/research/thecommon-sense-census-media-use-by-kids-age-zeroto-eight-2017.(Accessed onDecember 13, 2018).

26. Radesky JS, Weeks HM, Ball R, et al. Young children's use of smartphones and tablets. Pediatrics 2020; 146: e20193518. 
27. Kagitcibasi C, Ataca B. Value of children and family change: a three-decade portrait from Turkey. Appl Psychol 2005; 54: 317-337.

28. Roberts DF. Media and youth: access, exposure, and privatization. J Adolesc Health 2000; 27(Suppl 2): 8-14.

29. Thompson AL, Adair LS, Bentley ME. Maternal characteristics and perception of temperament associated with infant TV exposure. Pediatrics 2013; 131: e390-e397.

30. Radesky JS, Silverstein M, Zuckerman B, Christakis DA. Infant self-regulation and early childhood media exposure. Pediatrics 2014; 133: e1172-e1178.

31. Asplund KM, Kair LR, Arain YH, Cervantes M, Oreskovic NM, Zuckerman KE. Early childhood screen time and parental attitudes toward child television viewing in a low-income Latino population attending the special supplemental nutrition program for women, infants, and children. Child Obes 2015; 11: 590-599.

32. Li X, Newman J, Li D, Zhang H. Temperament and adolescent problematic Internet use: the mediating role of deviant peer affiliation. Comput Hum Behav 2016; 60: 342-350.

33. Lee YS, Son JH, Park JH, Kim SM, Kee BS, Han DH. The comparison of temperament and character between patients with internet gaming disorder and those with alcohol dependence. J Ment Health 2017; 26: 242-247.

34. Qiu X, Martin GB, Blache D. Gene polymorphisms associated with temperament. J Neurogenet 2017; 31: 1-16.
35. Ebstein RP. The molecular genetic architecture of human personality: beyond self-report questionnaires. Mol Psychiatry 2006; 11: 427-445.

36. Jago R, Davison KK, Thompson JL, Page AS, Brockman R, Fox KR. Parental sedentary restriction, maternal parenting style, and television viewing among 10-to 11-year-olds. Pediatrics 2011; 128: e572-e578.

37. Veldhuis L, van Grieken A, Renders CM, Hirasing RA, Raat H. Parenting style, the home environment, and screen time of 5-year-old children; the 'be active, eat right'study. PLoS One 2014; 9: e88486.

38. Bae SM. The relationships between perceived parenting style, learning motivation, friendship satisfaction, and the addictive use of smartphones with elementary school students of South Korea: using multivariate latent growth modeling. Sch Psychol Int 2015; 36: 513-531.

39. Radesky JS, Schumacher J, Zuckerman B. Mobile and interactive media use by young children: the good, the bad, and the unknown. Pediatrics 2015; 135: 1-3.

40. Zhang G, Wu L, Zhou L, Lu W, Mao C. Television watching and risk of childhood obesity: a metaanalysis. Eur J Public Health 2015; 26: 13-18.

41. Rubin KH, Burgess KB, Hastings PD. Stability and social-behavioral consequences of toddlers' inhibited temperament and parenting behaviors. Child Dev 2002; 73: 483-495.

42. Barr R, Kirkorian H, Radesky J, et al. Beyond screen time: a synergistic approach to a more comprehensive assessment of family media exposure during early childhood. Front Psychol 2020; 11: 1283. 